\title{
Kompetensi Auditor, Independensi, Skeptisme Profesional dan Kualitas Audit
}

\author{
Renaldi', Rizal Mawardi ${ }^{2}$ \\ 1, 2 Perbanas Institute \\ 1renaldialdi579@gmail.com; ${ }^{2}$ rizal.mawardi@perbanas.id \\ ${ }^{*}$ Penulis korespondensi
}

\begin{abstract}
The emergence of several cases that befell well-known Public Accounting Firms in Indonesia makes researchers want to test so that the purpose of this study is to determine the effect of auditor competence, auditor independence, and professional skepticism on audit quality. This study uses a survey method with a questionnaire. The sample in this study is an auditor who works at a Public Accounting Firm in South Jakarta. The sampling technique used was random sampling method. The sample of this research was conducted in 10 Public Accounting Firms with 77 auditors as respondents. The results of this study indicate that auditor competence, auditor independence, and professional skepticism have a positive effect on audit quality. This result implies that it is important for an auditor to have adequate competence, independent attitude and professional skepticism while carrying out audit engagements.
\end{abstract}

Keywords: auditor competence, independence, professional skepticism and audit quality

\begin{abstract}
Abstrak
Munculnya beberapa kasus yang menimpa Kantor Akuntan Publik ternama di Indonesia membuat peneliti ingin menguji sehingga tujuan penelitian ini adalah untuk mengetahui pengaruh kompetensi auditor, independensi auditor, dan skeptisme profesional terhadap kualitas audit. Penelitian ini menggunakan metode survei dengan kuisioner. Sampel dalam penelitian ini adalah auditor yang bekerja di Kantor Akuntan Publik di Jakarta Selatan. Teknik pengambilan sampel menggunakan metode random sampling. Sampel penelitian ini dilakukan di 10 Kantor Akuntan Publik dengan 77 auditor sebagai responden. Hasil penelitian ini menunjukan bahwa kompetensi auditor, independensi auditor, dan skeptisme profesional berpengaruh positif terhadap kualitas audit. Hasil ini memberikan implikasi bahwa pentingnya bagi seorang Auditor memiliki Kompetensi yang memadai, sikap Independen serta Skeptisme Profesionalisme selama melaksanakan Perikatan Audit.
\end{abstract}

Kata Kunci: kompetensi auditor, independensi, skeptisme profesional dan kualitas audit 


\section{PENDAHULUAN}

Dalam era persaingan global ini peran auditor sangat dibutuhkan oleh perusahaan, karena perusahaan pada umumnya menginginkan agar penyusunan dan penyajian laporan keuangannya bertujuan umum sesuai dengan Standar Akuntansi Keuangan yaitu PSAK 1 tentang penyajian laporan keuangan. Mengingat betapa pentingnya menjaga kualitas laporan keuangan agar terciptanya kepercayaan publik terhadap keakuratan dan validitas laporan keuangan auditan yang diterbitkan oleh auditor, tentu sudah menjadi kewajiban bagi para akuntan publik menjaga dan meningkatkan kualitas auditnya. Dengan kata lain, keberadaan auditor ditentukan oleh independensinya (Faturachman \& Nugraha, 2015). Seorang auditor diharapkan dapat memegang teguh etika profesi yang sudah ditetapkan oleh Institut Akuntan Publik Indonesia (IAPI) agar situasi persaingan tidak sehat dapat dihindarkan (Kitiwong \& Sarapaivanich, 2020).

Urgensi Penelitian ini menyorot pada profesi auditor telah menjadi perbincangan hangat praktisi bisnis Indonesia beberapa tahun terakhir. Adanya kasus yang membuat nama beberapa kantor akuntan publik menjadi diragukan, seperti halnya kasus kejanggalan laporan keuangan PT Garuda Indonesia yang diakibatkan karena adanya dugaan audit yang tidak sesuai dengan standar akuntansi. seharusnya Garuda Indonesia mencatatkan rugi senilai USD 244,95 juta di tahun 2018. Namun dalam laporan keuangan malah tercatat sepanjang tahun 2018 perusahaan mencetak laba bersih USD 809,84 ribu, meningkat tajam dari tahun 2017 yang rugi USD 216,58 juta. Hal tersebut membuat Kementerian Keuangan menjatuhkan sanksi pembekuan izin kepada akuntan publik Kasner Sirumapea selama 12 bulan. Kasner Sirumapea di nilai tidak mematuhi standar audit. Selain itu kredibilitas dan kualitas auditor semakin dipertanyakan, hal tersebut juga mengakibatkan Kantor Akuntan Publik (KAP) Tanubrata Sutanto Fahmi Bambang \& Rekan (Member of BDO Internasional) mendapat sanksi peringatan tertulis dan wajib melakukan perbaikan terhadap sistem pengendalian mutu, kompetensi, independensi serta skeptisme professional auditor.

Kasus lainnya pada kasus berikutnya yang cukup menyita perhatian dunia adalah kasus yang menyerang perusahaan teknologi yang telah berdiri 140 tahun yaitu Toshiba Corporation. Kasus ini mulai terungkap pada bulan juli 2015, kasus ini bermula atas inisiatif pemerintah Jepang untuk mendorong transparansi yang lebih besar pada perusahaanperusahaan di Jepang untuk menarik lebih banyak investasi asing. Berdasarkan saran pemerintah tersebut, Toshiba menyewa panel independen yang terdiri dari para akuntan public dan pengacara untuk menyelidiki masalah transparansi di perusahaan Toshiba. Panel independen yang dibentuk mengungkapkan pada laporan auditnya bahwa terdapat tiga direksi yang telah berperan aktif dalam menggelembungkan laba usaha Toshiba sebesar $¥ 151,8$ miliar atau setara dengan 1,22 miliar USD dalam kurun waktu lima tahun yaitu sejak tahun 2008. Panel independen tersebut mengatakan bahwa eksekutif perusahaan telah menekan unit bisnis perusahaan. Mulai dari unit personal computer sampai ke unit semikonduktor dan reactor nuklir untuk mencapai target laba yang tidak realistis.

Faturachman \& Nugraha (2015) dan Xiao dkk. (2020) menyatakan kompetensi auditor yang dimiliki seorang auditor dapat menambah kepercayaan terhadap pihak yang 
membutuhkan hasil dari audit, karena kompeteansi auditor adalah kemampuan auditor untuk mengaplikasikan pengetahuan dan pengalaman yang dimilikinya dalam melakukan audit sehingga auditor dapat melakukan audit dengan teliti, cermat, dan obyektif. Selain Kompetensi auditor, Independensi akuntan publik merupakan dasar utama kepercayaan masyarakat terhadap profesi akuntan publik dan merupakan salah satu faktor yang sangat penting untuk menilai mutu jasa audit. Menurut Alfiati (2017) skeptisme profesional diartikan sebagai sikap yang tidak mudah percaya akan bukti audit yang disajikan manajemen, sikap yang selalu mempertanyakan dan evaluasi bukti audit secara kritis. Skeptisme profesional sangat penting untuk dimiliki oleh auditor guna mendapatkan informasi yang kuat, yang akan dijadikan dasar bukti audit yang relevan untuk mendukung pemberian opini atas kewajaran laporan keuangan.

Pentingnya meningkatkan kualitas audit juga didukung oleh beberapa penelitian sebelumnya. Berdasarkan hasil Penelitian yang dilakukan oleh Anugrah dkk., (2017) menunjukkan kompetensi tidak berpengaruh terhadap kualitas audit, hasil penelitian tersebut terbanding terbalik dengan penelitian yang dilakukan oleh Siahaan \& Simanjuntak (2019) yang menyatakan bahwa kompetensi berpengaruh terhadap kualitas audit. Sedangkan penelitian yang dilakukan oleh Anugrah dkk., (2017), Pitaloka \& Widanaputra (2016), Shintya dkk. (2016), dan Nurhayati (2017) menunjukkan bahwa independensi berpengaruh positif terhadap kualitas audit. Semakin tinggi tingkat independensi yang diterapkan maka semakin baik pula kualitas audit yang dihasilkan oleh auditor. Hasil penelitian lainnya yang berbeda yaitu Fietoria \& Manalu (2016) dan Oklivia \& Marlinah (2014) menunjukkan bahwa independensi tidak berpengaruh positif terhadap kualitas audit.

Terdapat juga perbedaan penelitian yang dilakukan oleh Fietoria \& Manalu (2016) yang menunjukan bahwa skeptisme profesional tidak berpengaruh positif terhadap kualitas audit. Berbanding terbalik dengan penelitian yang dilakukan oleh Oklivia \& Marlinah (2014) dan Alfiati (2017) dalam penelitiannnya menunjukan bahwa skeptisme profesional berpengaruh signifikan positif terhadap kualitas audit.

Motivasi penelitian ini adalah menguji kompetensi auditor, independensi, skeptisme profesional yang berperan penting pada hasil kualitas audit. Peneliti mengharapkan hasil dari penelitian ini dapat berkontribusi langsung kepada Kantor Akuntan Publik (KAP) untuk selalu memperhatikan kompetensi, indenpendensi serta skeptisme professional saat menjalankan perikatan audit (Cho dkk., 2021). Kebaharuan dalam penelitian ini yaitu peneliti melakukan observasi auditor di Kantor Akuntan Publik (KAP) yang berada di Jakarta Selatan ditengah adanya perubahan pola audit dimasa pandemi Covid-19 sehingga hal ini juga menjadi daya tarik perlu dilakukan pengujian terkait kualitas audit.

\section{Pengaruh Kompetensi Auditor Terhadap Kualitas Audit}

Kompetensi merupakan kemampuan pengetahuan dan pengalaman auditor yang cukup dalam melakukan audit laporan keuangan secara objektif, cermat dan seksama (Nofiyanti, 2009). Dalam berbagai standar yang berlaku, kompetensi harus dimiliki oleh setiap auditor yang melakukan kegiatan audit karena dengan kompetensi dapat mempengaruhi kualitas 
audit. Standar umum pertama SKPN (Standar Pemeriksaan Keuangan Negara) menyebutkan bahwa pemeriksaan secara kolektif harus memiliki kecekapan profesional yang memadai untuk melaksanakan tugas pemeriksaan. Dengan pernyataan standar pemeriksaan ini semua organisasi pemeriksa bertanggung jawab untuk memastikan bahwa setiap pemeriksaan dilakukan oleh para pemeriksa yang secara kolektif memiliki pengetahuan, keahlian dan pengalaman yang dibutuhkan untuk melaksanakan tugas tersebut. Alfiati (2017) menyatakan apabila auditor yang kompeten dan kompetensi professionalnya diakui sangat baik, maka kualitas hasil audit yang dihasilkan berkualitas, begitu sebaliknya apabila kompetensi auditor kurang diakui diindikasikan pelaksanaan audit di entitas tersebut juga akan menghasilkan kualitas audit yang tidak berkualitas. Dapat disimpulkan bahwa kompetensi yang dimiliki oleh seorang auditor memiliki pengaruh yang signifikan terhadap kualitas hasil laporan keuangan (Nofiyanti, 2009). Jika kompetensi yang dimiliki oleh seorang auditor baik maka akan menghasilkan laporan hasil audit yang lebih baik. Dan sebaliknya, jika kompetensi yang dimiliki oleh auditor buruk maka akan menurunkan nilai dari kualitas hasil audit tersebut. Dengan penjelasan tersebut, maka dapat dirumuskan hipotesis berikut:

\section{H1: Kompetensi auditor berpengaruh positif terhadap kualitas audit}

\section{Pengaruh Independensi Auditor Terhadap Kualitas Audit}

Independensi adalah sikap dan prinsip jujur yang harus ditegakkan oleh auditor pada saat melaksanakan tugas auditnya. Independensi berarti sikap mental yang tidak bisa dipengaruhi, tidak bergantung, dan tidak bisa dikendalikan oleh pihak manapun (Kurniawan, 2019). Faturachman \& Nugraha (2015) menyatakan bahwa auditor harus memiliki sikap independen dalam melaksanakan tugas dengan mengacu pada prinsip auditing yang telah di bentuk. Auditor yang independen dapat menghasilkan kualitas audit yang memadai. Independensi sebagai suatu sikap di mana auditor tidak memihak harus selalu dapat dipertahankan. Sikap ketidakberpihakan yang ditunjukkan auditor ketika melaksanakan tugasnya mencerminkan auditor jujur dan bebas dari pengaruh apapun, sehingga kualitas laporan auditnya dapat di percaya dan akurat. Dengan penjelasan tersebut, maka dapat dirumuskan hipotesis berikut:

\section{H2: Independensi auditor berpengaruh positif terhadap kualitas audit}

\section{Pengaruh Skeptisme Profesional Terhadap Kualitas Audit}

Skeptisme profesional auditor menurut Agoes (2012) menyatakan bahwa "Skeptisme Profesional merupakan sikap yang penuh dengan pertanyaan di dalam benaknya serta sikap penilaian kritis atas setiap bukti audit yang diperoleh". Skeptisme profesional diartikan sebagai sikap yang tidak mudah percaya akan bukti audit yang disajikan manajemen, sikap yang selalu mempertanyakan dan evaluasi bukti audit secara kritis. Fietoria \& Manalu (2016) menyatakan bahwa auditor dituntut untuk selalu cermat dan seksama dalam menggunakan kemahiran profesionalnya. Skeptisisme perlu diperhatikan oleh auditor profesional agar hasil pemeriksaan laporan keuangan dapat dipercaya oleh orang yang membutuhkan laporan tersebut. Dalam praktik yang dilakukan oleh akuntan publik, Sebagian masyarakat masih 
meragukan tingkat skeptis yang dimiliki oleh auditor sehingga berdampak pada keraguan. Dengan penjelasan tersebut, maka dapat dirumuskan hipotesis berikut:

\section{H3: Skeptisme Profesional berpengaruh positif terhadap kualitas audit}

\section{METODE}

\section{Desain Penelitian}

Penelitian ini di buat untuk mengkaji hipotesis dengan melakukan pengujian mengenai pengaruh kompetensi, independensi, dan skeptisme profesional terhadap kualitas audit. Variabel yang digunakan dalam penelitian ini adalah kompetensi, independensi, skeptisme profesional dan kualitas audit. Jenis data yang digunakan dalam penelitian ini adalah data primer. Penelitian ini merupakan penelitian kuantitatif. Penggunaan metode penelitian kuantitatif dalam penelitian ini di nilai tepat dan sesuai dikarenakan penlitian ini menggunakan angka-angka sebagai indikator variabel penelitian. Penelitian ini menggunakan metode kuantitatif sebagai pendekatan untuk menganalisis permasalahan penelitian ini seperti yang telah dijelaskan sebelumnya. Kuesioner yang telah diisi kemudian dikembalikan kepada peneliti untuk diolah lebih lanjut menggunakan metode yang telah ditentukan.

\section{Unit Analisis}

Dalam penelitian ini menggunakan individu sebagai unit analisis. Responden dalam penelitian ini adalah auditor di Kantor Akuntan Publik (KAP) yang berada di Jakarta Selatan. Tabel 1 menyajikan rincian sampel penelitian.

Tabel 1 Daftar Sampel Penelitian Kantor Akuntan Publik di Jakarta Selatan

\begin{tabular}{|c|c|c|}
\hline No & Nama Kantor Auntan Publik & Alamat \\
\hline 1 & Tasnim Ali Widjanarko \& Rekan & $\begin{array}{l}\text { Menara Kadin Indonesia Lt. } 2 \text { \& 9, Jl. H.R. Rasuna Said Blok } \\
\text { X-5 Kav. 2-3, Jakarta } 12950\end{array}$ \\
\hline 2 & Rama Wendra & $\begin{array}{l}\text { Graha Mampang, 2nd Floor, Jl. Mampang Prapatan no. 100, } \\
\text { Jakarta Rt.2/RW.1, Duren Tiga, Pancoran, South Jakarta City, } \\
\text { Jakarta } 12760\end{array}$ \\
\hline 3 & Gideon Adi dan Rekan & $\begin{array}{l}\text { Plaza Sentral Lt. 7, Jl. Jend. Sudirman Kav. 47, Jakarta Selatan } \\
12930\end{array}$ \\
\hline 4 & Yosua \& Rekan & $\begin{array}{l}\text { Graha Mampang, Jl. Mampang Prpt. Raya No.100, Tegal Parang, } \\
\text { Kec. Mampang Prpt., Kota Jakarta Selatan } 12790\end{array}$ \\
\hline 5 & Drs. A Salam Rauf \& Rekan & $\begin{array}{l}\text { Jl. Pancoran Barat X No. } 7 \text { RT.010/ 004, Pancoran, Jakarta } \\
\text { Selatan } 12780\end{array}$ \\
\hline 6 & Husni, Mucharam \& Rasidi & $\begin{array}{l}\text { Komplek Perkantoran Royal Palace Blok C-18, Jl Prof DR } \\
\text { Soepomo, SH No. } 178 \text { A, Jakarta } 12870\end{array}$ \\
\hline 7 & Morhan \& Rekan & Generali Tower, 8th Floor Jl. HR. Rasuna Said Jakarta Selatan \\
\hline 8 & Kanaka Puradiredja, Suhartono & $\begin{array}{l}\text { The Royal Palace, Jl Prof. Dr. Soepomo No. } 178 \text { A - C } 29 \text {, } \\
\text { Jakarta } 12810\end{array}$ \\
\hline 9. & Bhrata, Arifin, Mumajad \& Sayuti & $\begin{array}{l}\text { JL. Raya Rawa Bambu. No 170. Pasar Minggu, Jakarta Selatan. } \\
12520\end{array}$ \\
\hline
\end{tabular}




\begin{tabular}{cll}
\hline No & \multicolumn{1}{c}{ Nama Kantor Auntan Publik } & \multicolumn{1}{c}{ Alamat } \\
\hline 10. & $\begin{array}{l}\text { Doli, Bambang, Sulistiyanto, } \\
\text { Dadang \& Ali }\end{array}$ & $\begin{array}{l}\text { Menara Kuningan 11th Floor, Jl HR Rasuna Said Blok X-7 } \\
\text { Kav 5, Jakarta 12940 }\end{array}$ \\
\hline 11. & $\begin{array}{l}\text { Tanubrata Sutanto Fahmi Bambang } \\
\text { \& Rekan }\end{array}$ & $\begin{array}{l}\text { Prudential Tower Lt.17, Jalan Jend. Sudirman Kav. 79, Jakarta } \\
12910\end{array}$ \\
\hline 12. & Nugroho \& Rekan & $\begin{array}{l}\text { Gedung Lina Lantai 2 Ruang 204, Jl. HR Rasuna Said Kav.B-7 } \\
\text { Jakarta Selatan 12910 }\end{array}$ \\
\hline 13. & Teguh Heru \& Rekan & $\begin{array}{l}\text { Graha THI, Jl. KH Abdullah Safei No. 11, Lapangan Roos, } \\
\text { Tebet, Jakarta Selatan 12860 }\end{array}$ \\
\hline 14. & Aidil Yuzar & $\begin{array}{l}\text { Gedung 47, Ruang 203, Jln. TB Simatupang 47, Tanjung } \\
\text { Barat, Jagakarsa, Rt.5/RW.5, Tj Barat, Kec Jagakarsa, Jakarta } \\
\text { Selatan, 12530 }\end{array}$ \\
\hline & & $\begin{array}{l}\text { Gedung Permata Kuningan Lantai 5, Jl. Kuningan Mulia } \\
\text { Kav. 9C, RT.6 / RW.1, Guntur, Kec. Setiabudi, Kota Jakarta } \\
\text { 15. Anwar dan Rekan }\end{array}$ \\
\hline
\end{tabular}

Sumber: data diolah, 2021

\section{Operasional Varibel Penelitian}

Penelitian ini menggunakan empat variabel yang akan dianalisis. Keempat variabel tersebut secara konsep dapat dibedakan menjadi variabel terikat (dependent variable) dan variabel bebas (independent variable). Variabel terikat yaitu kualitas audit (Y), variabel bebas yaitu kompetensi (X1), independensi (X2), dan Skeptisme Profesional (X3). Berikut ini merupakan penjelasan mengenai oprasional variabel penelitian.

\section{Teknik Analisis}

Metode analisis data dalam penelitian ini menggunakan metode analisis regresi berganda (multiple regression analysis). Uji analisis ini digunakan untuk mengetahui sejauh mana pengaruhi kompetensi, independensi, dan tekanan anggaran waktu pada kualitas audit. Model persamaan regresi yang digunakan dalam pengujian hipotesis yaitu:

$$
\text { Kualitas Audit }=a+\beta 1 X 1+\beta 2 X 2+\beta 3 X 3+e
$$

\section{HASIL DAN PEMBAHASAN}

\section{Distribusi Responden}

Penelitian ini dilakukan kepada auditor yang bekerja di KAP di wilayah Jakarta Selatan. Data yang diperoleh dalam penelitian ini adalah dengan cara mengantarkan langsung kuesioner kepada responden yang dalam penelitian ini adalah auditor - auditor eksternal yang bekerja di Kantor Akuntan Publik di wilayah Jakarta Selatan. Dalam penelitian ini penyebaran kuisioner sebanyak 100 kuisioner dan kuisioner yang kembali sebanyak 77 kuisioner (respon rate 77\%). Dari 77 kuisioner yang diperoleh seluruhnya dapat di olah. Berikut ini adalah rincian nama-nama KAP yang menjadi objek penelitian ini dalam tabel 2. 
Tabel 2 Daftar KAP dan Jumlah Responden

\begin{tabular}{cll}
\hline No. & \multicolumn{1}{c}{ Nama Kantor Akuntan Publik } & Jumlah Responden \\
\hline 1. & Tasnim Ali Widjanarko \& Rekan & 10 \\
2. & Rama Wendra & 10 \\
3. & Gideon Adi dan Rekan & 7 \\
4. & Yosua \& Rekan & 5 \\
5. & Drs. A Salam Rauf \& Rekan & 8 \\
6. & Husni, Mucharam \& Rasidi & 7 \\
7. & Morhan \& Rekan & 5 \\
8. & kanaka Puradiredja, Suhartono & 7 \\
9. & Bhrata, Arifin, Mumajad \& Sayuti & 10 \\
10. & Doli, Bambang, Sulistiyanto, Dadang \& Ali & 8 \\
\hline & Jumlah Responden (n) & $\mathbf{7 7}$ \\
\hline
\end{tabular}

Sumber: data diolah, 2021

\section{Statistik Deskriptif dan Profil Responden}

Berdasarkan data demografis dari objek penelitian ini, maka dapat dijabarkan mengenai gambaran umum profil dari responden yang berpartisipasi dalam pengisian kuesioner yang disebarkan untuk penelitian ini. Pada tabel 3 dijelaskan secara singkat profil responden berdasarkan jenis kelamin, usia, posisi terakhir, pendidikan terakhir dan lama bekerja di KAP. Sementara itu, tabel 4 menunjukkan statistik deskriptif responden berdasarkan varibel penelitian yaitu, kompetensi auditor, independensi, skeptismen profesional, dan kualitas audit.

Tabel 3 Profil Responden

\begin{tabular}{lcc}
\hline \multicolumn{1}{c}{ Karakteristik } & Frekuensi & Presentase \\
\cline { 1 - 2 } Jenis Kelamin & 43 & $55,8 \%$ \\
Laki-Laki & 34 & $44,2 \%$ \\
Perempuan & & \\
\hline Usia & 68 & $88,3 \%$ \\
\hline 20 - 30 tahun & 7 & $9,1 \%$ \\
31 - 50 tahun & 2 & $2,6 \%$ \\
$>50$ tahun & & \\
\hline Posisi Jabatan KAP & & $1,3 \%$ \\
\hline Partner & & $6,5 \%$ \\
Manajer & & $2,6 \%$ \\
Supervisor & & $29,9 \%$ \\
Senior Auditor & $59,7 \%$ \\
Junior Auditor & & \\
\hline
\end{tabular}

Sumber: data diolah, 2021 
Berdasarkan data pada tabel 3, responden penelitian didominasi oleh laki-laki sebesar $55,8 \%$. Rentang usia responden paling banyak ada di usia 20-30 tahun, yaitu sebanyak 68 orang. Sementara itu, reponden penelitian ini paling banyak menduduki posisi sebagai junior auditor, sebanyak 46 orang atau 59,7\%.

Tabel 4 Statistik Deskriptif

\begin{tabular}{lccccc}
\hline \multicolumn{1}{c}{ Variabel } & N & Minimum & Maximum & Mean & Std. Deviation \\
\hline Kompetensi Auditor & 77 & 36.00 & 50.00 & 41.0260 & 2.67530 \\
Independensi & 77 & 36.00 & 46.00 & 39.2468 & 3.41111 \\
Skeptisme Profesional & 77 & 35.00 & 44.00 & 40.2208 & 2.23973 \\
Kualitas Audit & 77 & 31.00 & 45.00 & 39.8442 & 2.78655 \\
Valid N (listwise) & 77 & & & & \\
\hline
\end{tabular}

Sumber: data diolah, 2021

Berdasarkan tabel 4 dapat diketahui bahwa variabel kompetensi auditor memiliki nilai minimum 36 dan nilai maksimum 50 dengan nilai rata-rata 41,0260 dan standar deviasi sebesar 2,67530, nilai rata-rata lebih besar jika dibandingkan dengan nilai standar deviasi, yang artinya nilai rata-rata tersebut merupakan representasi yang baik dari keseluruhan data penelitian. Variabel independensi auditor memiliki nilai minimum 36 dan nilai maksimum 46 dengan nilai rata-rata 39,2468 dan standar deviasi sebesar 3,41111, nilai rata-rata lebih besar jika dibandingkan dengan nilai standar deviasi, yang artinya nilai ratarata tersebut merupakan representasi yang baik dari keseluruhan data penelitian. Variabel skeptisme profesional memiliki nilai minimum 35 dan nilai maksimum 44 dengan nilai rata-rata 40,2208 dan standar deviasi sebesar 2,23973, nilai rata-rata lebih besar jika dibandingkan dengan nilai standar deviasi, yang artinya nilai rata-rata tersebut merupakan representasi yang baik dari keseluruhan data penelitian. Variabel kualitas audit memiliki nilai minimum 31 dan nilai maksimum 45 dengan nilai rata-rata 39,8442 dan standar deviasi sebesar 2,78655, nilai rata-rata lebih besar jika dibandingkan dengan nilai standar deviasi, yang artinya nilai ratarata tersebut merupakan representasi yang baik dari keseluruhan data penelitian. 


\section{Hasil Uji Analisis Data}

\section{Uji Validitas}

Hasil uji validitas disajikan pada tabel 5 berikut ini:

Tabel 5 Hasil Uji Validitas

\begin{tabular}{|c|c|c|c|}
\hline Variabel & R Hitung & R Tabel & Keterangan \\
\hline \multicolumn{4}{|c|}{ Kompetensi Auditor } \\
\hline 1 & 0,605 & 0,224 & Valid \\
\hline 2 & 0,756 & 0,224 & Valid \\
\hline 3 & 0,460 & 0,224 & Valid \\
\hline 4 & 0,454 & 0,224 & Valid \\
\hline 5 & 0,624 & 0,224 & Valid \\
\hline 6 & 0,460 & 0,224 & Valid \\
\hline 7 & 0,624 & 0,224 & Valid \\
\hline 8 & 0,605 & 0,224 & Valid \\
\hline 9 & 0,437 & 0,224 & Valid \\
\hline 10 & 0,350 & 0,224 & Valid \\
\hline \multicolumn{4}{|c|}{ Independensi Auditor } \\
\hline 1 & 0,644 & 0,224 & Valid \\
\hline 2 & 0,629 & 0,224 & Valid \\
\hline 3 & 0,650 & 0,224 & Valid \\
\hline 4 & 0,632 & 0,224 & Valid \\
\hline 5 & 0,856 & 0,224 & Valid \\
\hline 6 & 0,632 & 0,224 & Valid \\
\hline 7 & 0,856 & 0,224 & Valid \\
\hline 8 & 0,629 & 0,224 & Valid \\
\hline 9 & 0,856 & 0,224 & Valid \\
\hline 10 & 0,635 & 0,224 & Valid \\
\hline \multicolumn{4}{|c|}{ Skeptisme Profesioanal } \\
\hline 1 & 0,375 & 0,224 & Valid \\
\hline 2 & 0,598 & 0,224 & Valid \\
\hline 3 & 0,539 & 0,224 & Valid \\
\hline 4 & 0,521 & 0,224 & Valid \\
\hline 5 & 0,270 & 0,224 & Valid \\
\hline 6 & 0,333 & 0,224 & Valid \\
\hline 7 & 0,440 & 0,224 & Valid \\
\hline 8 & 0,438 & 0,224 & Valid \\
\hline 9 & 0,440 & 0,224 & Valid \\
\hline 10 & 0,568 & 0,224 & Valid \\
\hline \multicolumn{4}{|c|}{ Kualitas Audit } \\
\hline 1 & 0,703 & 0,224 & Valid \\
\hline 2 & 0,689 & 0,224 & Valid \\
\hline 3 & 0,703 & 0,224 & Valid \\
\hline 4 & 0,504 & 0,224 & Valid \\
\hline 5 & 0,255 & 0,224 & Valid \\
\hline 6 & 0,427 & 0,224 & Valid \\
\hline 7 & 0,571 & 0,224 & Valid \\
\hline 8 & 0,316 & 0,224 & Valid \\
\hline 9 & 0,703 & 0,224 & Valid \\
\hline 10 & 0,384 & 0,224 & Valid \\
\hline
\end{tabular}

Sumber: data diolah, 2021 
Berdasarkan hasil pengujian validitas, dapat disimpulkan bahwa butir-butir pertanyaan setiap variabel merupakan butir pertanyaan yang dapat dinyatakan valid dimana $r$ hitung lebih besar dari $r$ tabel dengan nilai $r$ tabel sebesar 0,224.

\section{Uji Reliabilitas}

Hasil uji reliabilitas disajikan pada tabel 6 berikut ini:

Tabel 6 Hasil Uji Reliabilitas

\begin{tabular}{lcc}
\hline \multicolumn{1}{c}{ Variabel } & Cronbach's alpha & Keterangan \\
\hline Kompetensi Auditor & 0,714 & Reliabel \\
Independensi Auditor & 0,754 & Reliabel \\
Skeptisme Profesional & 0,675 & Reliabel \\
Kualitas Audit & 0,715 & Reliabel \\
\hline
\end{tabular}

Sumber: data diolah, 2021

Berdasarkan hasil uji reliabilitas diatas, nilai cronbach's alpha yang dihasilkan pada tiap-tiap variabel lebih dari pada 0,6. Maka dapat dinyatakan bahwa tiap-tiap variabel memiliki data yang reliabel dan bisa digunakan dalam mengukur objek penelitian ini.

\section{Uji Normalitas}

Berikut ini merupakan hasil dari uji normalitas dengan metode normal probability plot:

\section{Gambar 1 Grafik Normal Plot}

Normal P-P Plot of Regression Standardized Residual

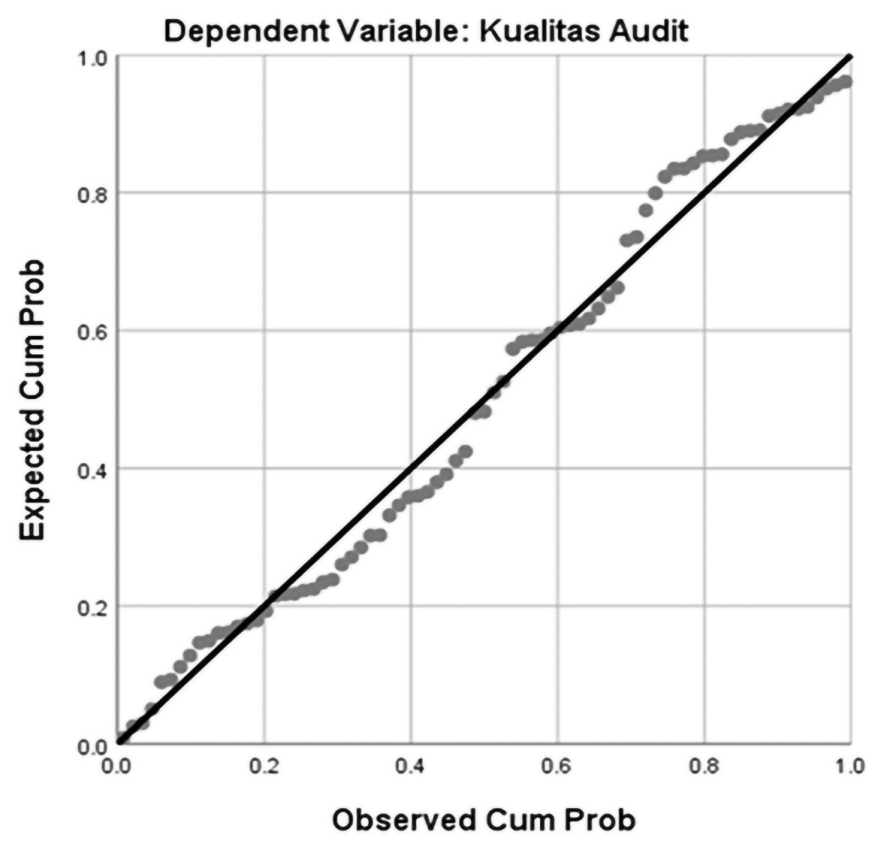


Berdasarkan gambar grafik normal plot tersebut menunjukkan titik-titik menyebar di sekitar garis diagonal dan mengikuti arah garis diagonal, maka dapat disimpulkan bahwa model regresi ini layak dipakai karena memenuhi asumsi normalitas.

\section{Uji Multikolonearitas}

Tabel 7 menunjukan hasi dari uji multikolonearitas:

Tabel 7 Hasil Uji Multikolonearitas

\begin{tabular}{llll}
\hline & & \multicolumn{2}{c}{ Collinearity Statistics } \\
\cline { 3 - 4 } & & Tolerance & VIF \\
\hline $1 \quad$ (Constant) & & \\
& Kompetensi Auditor & .936 & 1.068 \\
& Independensi & .708 & 1.413 \\
& Skeptisme Profesional & .687 & 1.455 \\
\hline
\end{tabular}

Sumber: data diolah, 2021

Berdasarkan hasil pada tabel 7, dapat dilihat bahwa setiap variabel independen memiliki nilai tolerance $>0,1$ dan nilai VIF $<10$. Maka dari itu analisis ini menunjukan bahwa semua variabel penelitian ini tidak terjadi multikolonearitas.

\section{Uji Heteroskedastisitas}

Hasil uji heteroskedastisitas disajikan pada Gambar 2:

\section{Gambar 2 Hasil Uji Heteroskedastisitas}

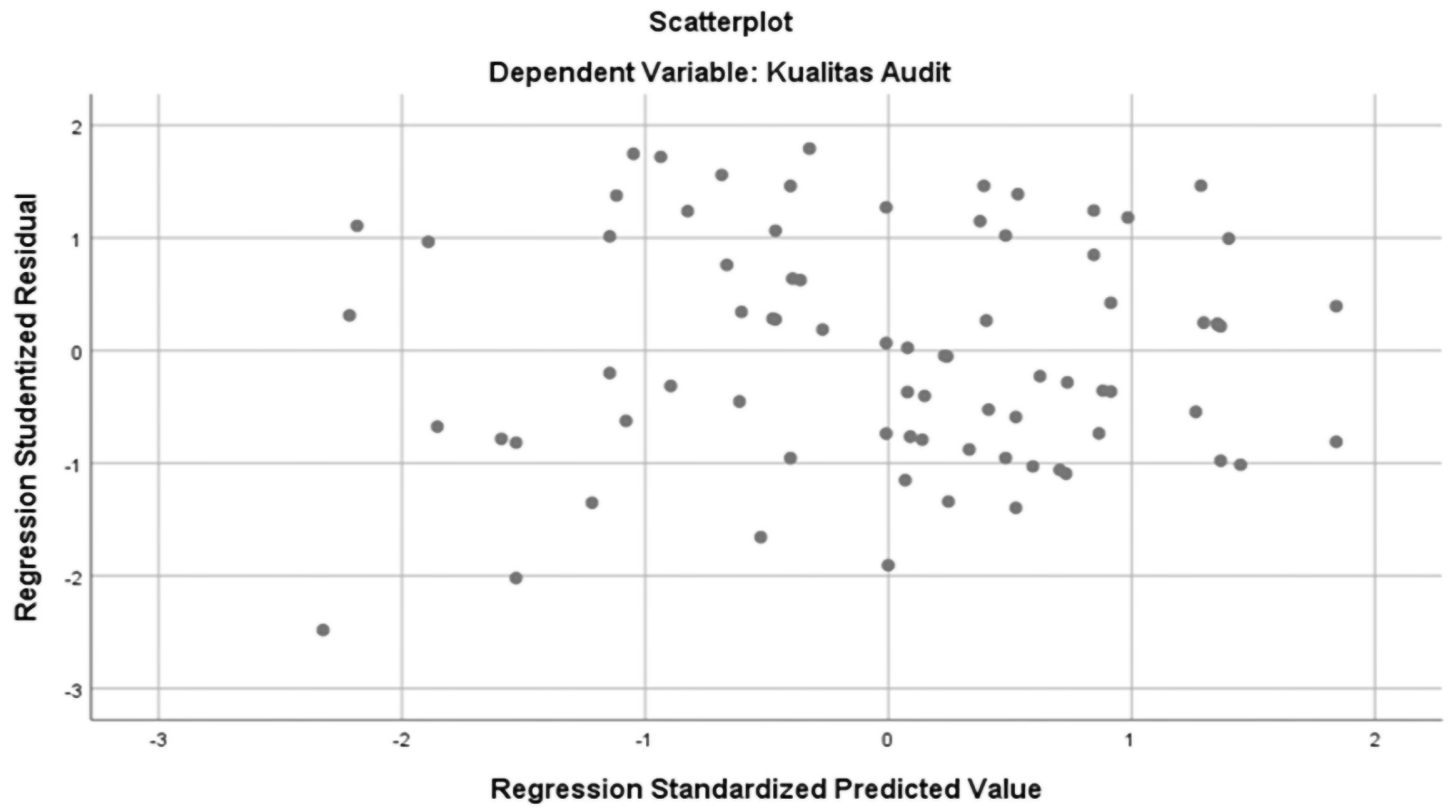


Berdasarkan grafik scatterplot diatas, titik-titik menyebar diatas dan dibawah angka 0 pada sumbu Y. Maka dapat disimpulkan bahwa tidak terjadi heteroskedastisitas, sehingga model regresi layak dipakai untuk melihat pengaruh variabel independen terhadap variabel dependen.

\section{Hasil Uji Hipotesis}

Uji $\mathrm{t}$ atau Uji parsial dilakukan guna mengetahui seberapa jauh pengaruh variabel independen yaitu kompetensi auditor, independensi auditor, dan skeptisme profesional terhadap variabel dependen kualitas audit secara parsial. Hasil uji t disajikan pada tabel berikut ini:

Tabel 8 Hasil Uji-t

\begin{tabular}{|c|c|c|c|c|c|c|}
\hline & \multirow{2}{*}{ Model } & \multicolumn{2}{|c|}{$\begin{array}{l}\text { Unstandardized } \\
\text { Coefficients }\end{array}$} & \multirow{2}{*}{$\begin{array}{c}\begin{array}{c}\text { Standardized } \\
\text { Coefficients }\end{array} \\
\text { Beta }\end{array}$} & \multirow{2}{*}{$\mathbf{t}$} & \multirow{2}{*}{ Sig. } \\
\hline & & B & $\begin{array}{l}\text { Std. } \\
\text { Error }\end{array}$ & & & \\
\hline \multirow[t]{4}{*}{1} & (Constant) & -9.432 & 3.042 & & -3.101 & .003 \\
\hline & Kompetensi Auditor & .701 & .092 & .524 & 7.600 & .000 \\
\hline & Independensi & .156 & .067 & .166 & 2.324 & .023 \\
\hline & Skeptisme Profesional & .420 & .102 & .334 & 4.102 & .000 \\
\hline
\end{tabular}

Sumber: data diolah, 2021

\section{Pengaruh Kompetensi Auditor Terhadap Kualitas Audit}

Variabel kompetensi auditor (X1) memiliki nilai p-value t sig sebesar 0,000<0,01 yang artinya lebih kecil dari nilai signifikansi 0,01. Berdasarkan hipotesis pertama yang diajukan yaitu "Kompetensi auditor berpengaruh positif terhadap kualitas audit" Hal ini menunjukkan bahwa hipotesis H1 diterima. Sehingga dapat disimpulkan bahwa kompetensi auditor berpengaruh positif terhadap kualitas audit. Hipotesis pertama yang diuji adalah kompetensi auditor menunjukan bahwa kompetensi berpengaruh positif terhadap kualitas audit. Berdasarkan hasil uji t yang menjelaskan bahwa kompetensi auditor berpengaruh positif terhadap kualitas audit melalui nilai sig sebesar 0,000. Hal ini menujukan bahwa semakin tinggi kompetensi yang dimiliki seorang auditor maka akan tinggi pula kualitas audit yang akan dihasilkan. Hasil dari penelitian ini mendukung penelitian sebelumnya yang telah dilakukan oleh Siahaan \& Simanjuntak (2019) dan Alfiati (2017) yang juga menyatakan bahwa kompetensi berpengaruh terhadap kualitas audit.

Berdasarkan analisis statistik dalam penelitian ini ditemukan bahwa kompetensi auditor berpengaruh positif terhadap kualitas audit. Maka dapat disimpulkan bahwa semakin tinggi kompetensi yang dimiliki seorang auditor maka hasil pemeriksaan yang dikerjakan akan semakin baik. Kompetensi ini berhubungan dengan pendidikan dan pengalaman auditor. Pendidikan akan membentuk dan menambah pengetahuan seorang auditor yang akan membantu dalam melakukan tugas auditnya. Selain itu, pengalaman yang dimiliki 
akan membentuk dan meningkatkan keterampilan kerjanya. Dengan demikian, pendidikan dan pengalaman menjadi dasar seorang auditor tersebut dikatakan memiliki kompetensi yang baik. Hasil penelitian ini mendukung pernyataan dari penelitian yang dilakukan oleh Siahaan \& Simanjuntak (2019) dan Alfiati (2017) yang mengemukakan bahwa kompetensi auditor berpengaruh positif terhadap kualitas audit. Hal ini menunjukan bahwa semakin tinggi tingkat kompetensi yang dimiliki seorang auditor maka semakin baik kualitas audit yang dihasilkan.

\section{Pengaruh Independensi Auditor Terhadap Kualitas Audit}

Variabel independensi auditor (X2) memiliki nilai p-value t sig sebesar 0,023 $<0,05$ yang artinya lebih kecil dari nilai signifikansi 0,05. Berdasarkan hipotesis kedua yang diajukan yaitu "Independensi auditor berpengaruh positif terhadap kualitas audit" Hal ini menunjukkan bahwa hipotesis H2 diterima. Sehingga dapat disimpulkan bahwa independensi auditor berpengaruh positif terhadap kualitas audit. Hipotesis kedua yang di uji adalah independensi auditor menunjukan bahwa independensi berpengaruh positif terhadap kualitas audit. Berdasarkan hasil uji t yang menjelaskan bahwa independensi auditor berpengaruh positif terhadap kualitas audit melalui nilai sig sebesar 0,023. Hal ini menujukan bahwa semakin tinggi independensi yang dimiliki seorang auditor maka akan tinggi pula kualitas audit yang akan dihasilkan. Hasil dari penelitian ini mendukung penelitian sebelumnya yang telah dilakukan oleh Anugrah dkk., (2017), Pitaloka \& Widanaputra (2016), Shintya dkk. (2016), dan Nurhayati (2017) menunjukkan bahwa independensi berpengaruh positif terhadap kualitas audit.

Hasil dari penelitian ini menghasilkan bahwa independensi berpengaruh positif terhadap kualitas audit. Seorang auditor yang mampu mempertahankan independensinya maka akan menghasilkan sebuah kualitas audit yang baik dan dapat dipercaya oleh masyarakat. Independensi itu berarti tidak mudah dipengaruhi, karena auditor melaksanakan pekerjaannya untuk kepentingan umum (dibedakan dalam hal berpraktik sebagai auditor intern). Independensi auditor terjaga apabila seorang auditor tidak terlalu lama dalam menjalin hubungan dengan klien. Auditor yang menjalin hubungan dengan auditee dalam jangka waktu yang lama akan cenderung mempunyai kedekatan yang mempengaruhi auditor dalam memberikan pendapat.

Penelitian ini menunjukan bukti kuat bahwa Auditor tidak dibenarkan memihak kepada kepentingan siapapun, bagaimanapun sempurnanya keahlian teknis yang auditor miliki, auditor akan kehilangan sikap tidak memihak yang justru paling penting untuk mempertahankan kebebasan pendapatnya, karena pentingnya independensi dalam menghasilkan kualitas audit maka para auditor harus memiliki sikap ini dalam melakukan tugasnya. Auditor yang mampu bekerja secara independen dan selalu mempertahankan independensinya cenderung akan bekerja lebih baik 70 dibandingkan dengan auditor yang tidak memiliki independensi sehingga hal tersebut berpengaruh terhadap kualitas audit yang dihasilkan.

Penelitian ini sejalan dengan hasil penelitian yang dilakukan oleh Anugrah dkk., (2017), Pitaloka \& Widanaputra (2016), Shintya dkk. (2016), dan Nurhayati (2017) yang 
menyatakan bahwa independensi auditor berpengaruh positif terhadap kualitas audit. Hal ini menunjukkan bahwa semakin independen seorang auditor maka semakin baik kualitas audit yang akan dihasilkan.

\section{Pengaruh Skeptisme Profesional Terhadap Kualitas Audit}

Variabel skeptisme profesional (X3) memiliki nilai p-value t sig sebesar 0,000 < 0,01 yang artinya lebih kecil dari nilai signifikansi 0,01. Berdasarkan hipotesis ketiga yang diajukan yaitu "skeptisme profesional berpengaruh positif terhadap kualitas audit" Hal ini menunjukkan bahwa hipotesis H3 diterima. Sehingga dapat disimpulkan bahwa skeptisme profesional berpengaruh positif terhadap kualitas audit. Hipotesis ketiga yang diuji adalah skeptisme profesional menunjukan bahwa skeptisme profesional berpengaruh positif terhadap kualitas audit. Berdasarkan hasil uji t yang menjelaskan bahwa skeptisme profesional berpengaruh terhadap kualitas audit melalui nilai sig sebesar 0,000. Hal ini menujukan bahwa semakin besar skeptisme profesional seorang auditor maka semakin bagus hasil dari kualitas Audit. Hasil dari penelitian ini mendukung penelitian sebelumnya yang telah dilakukan oleh Oklivia \& Marlinah (2014) dan Alfiati (2017) yang menyatakan bahwa skeptisme profesional berpengaruh terhadap kualitas audit.

Penelitian ini menghasilkan bahwa Skeptisme Profesional berpengaruh positif terhadap kualitas audit. Semakin baik skeptisme profesional seorang auditor dalam melaksanakan proses audit maka akan semakin meningkatkan kualitas audit. Karena skeptisme profesional sangat penting untuk dimiliki oleh auditor guna mendapatkan informasi yang kuat, yang akan dijadikan dasar bukti audit yang relevan yang dapat mendukung pemberian opini atas kewajaran laporan keuangan.

Peneliti menemukan bukti skeptisme professional sebagai sikap yang tidak mudah percaya akan bukti audit yang disajikan, sikap yang selalu mempertanyakan dan evaluasi bukti audit secara kritis. Skeptisme profesional sangat penting untuk dimiliki oleh auditor guna mendapatkan informasi yang kuat, yang akan dijadikan dasar bukti audit yang relevan untuk mendukung pemberian opini atas kewajaran laporan keuangan.

Hasil penelitian ini mendukung pernyataan dari penelitian yang dilakukan oleh Nofiyanti (2012) dan Alfiati (2017) yang menyatakan bahwa skeptisme profesional berpengaruh positif terhadap kualitas audit. Sikap skeptisme yang dimiliki seorang auditor akan mendorong auditor untuk mendapatkan informasi yang lebih kuat untuk dijadikan dasar bukti audit yang relevan sehingga dapat meningkatkan kualitas audit.

\section{SIMPULAN}

Penelitian ini bertujuan untuk menguji pengaruh kompetensi auditor, independensi auditor, dan skeptisme profesional terhadap kualitas audit. Subjek penelitian ini adalah auditor yang bekerja di Kantor Akuntan Publik di Jakarta Selatan yang terdaftar di Direktorat Institut Akuntan Publik Indonesia (IAPI).

Hasil penelitian memberikan implikasi dari bukti empiris bahwa terkait munculnya beberapa kasus yang menyerang reputasi Kantor Akuntan Publik (KAP) yang menjadi sorotan 
masyarakat membuat Auditor semakin melek pentingnya kualitas audit. Ini terlihat dari KAP di Jakarta Selatan yang rutin memberikan pelatihan bagi staf Auditornya terkait skill dan integritas. Selain itu, pentingnya kesadaran ketuhanan atau rohani serta faktor psikologis Auditor menjadi daya tarik sendiri yang bisa diteliti dalam penelitian selanjutnya. Hasil dari penelitian ini juga memberikan bukti teoritis pada Standar umum pertama SA seksi 210 (Institut Akuntan Publik Indonesia, 2011) menyebutkan bahwa audit harus dilaksanakan oleh seseorang atau lebih yang mempunyai keahlian dan pelatihan teknis yang cukup sebagai auditor. Betapapun tingginya kemampuan seseorang dalam bidang-bidang lain, termasuk dalam bidang bisnis dan keuangan, ia tidak dapat memenuhi persyaratan yang dimaksudkan dalam standar auditing ini, jika ia tidak memiliki pendidikan serta integritas memadai dalam bidang auditing. Ini berarti auditor wajib memiliki sikap kompetensi yang diperoleh melalui pengetahuan, keahlian, dan pengalaman Penelitian ini memiliki keterbatasan Objek Penelitian yang tidak dapat diobervasi oleh peneliti yakni hanya berasal dari 10 KAP di Jakarta Selatan dari jumlah keseluruhan KAP Jakarta Selatan sebanyak 15 KAP. Terdapat 5 KAP yang menolak untuk menerima kuesioner disebabkan adanya pembatasan kegiatan di Kantor Akuntan Publik selama masa pandemi Covid-19. Penelitian ini menggunakan metode pengumpulan data melalui kuesioner yang di tinggal di KAP sesuai waktu yang telah di sepakati sehingga dari data yang disebarkan sebanyak 100 sampel, hanya dapat memperoleh 77 sampel.

\section{PUSTAKA ACUAN}

Alfiati, R. (2017). Pengaruh Etika Auditor, Skeptisme Profesional dan Kompetensi Auditor terhadap Kualitas Hasil Audit (Studi Empiris pada Kantor Inspektorat Provinsi Sumatera Barat). Jurnal Akuntansi, 4, 9-15.

Agoes, S. (2012). Petunjuk Praktis Pemeriksaan Akuntan oleh Akuntan Publik. Jakarta: Salemba Empat

Anugrah, I., Kamaliah, K., \& Ilham, E. (2017). Pengaruh TIME Budget Pressure, Kompetensi dan Independensi terhadap Kualitas Audit dengan Etika Profesi sebagai Variable Moderasi. Jurnal Online Mahasiswa Fakultas Ekonomi Universitas Riau, 4(1), 1322-1336.

Cho, M., Kwon, S. Y., \& Krishnan, G. V. (2021). Audit fee lowballing: Determinants, recovery, and future audit quality. Journal of Accounting and Public Policy, 40(4), 106787. https:// doi.org/10.1016/j.jaccpubpol.2020.106787

Faturachman, T. A., \& Nugraha, A. (2015). Pengaruh Due Professional Care Terhadap Kualitas Audit Pada Kantor Akuntan Publik di Kota Bandung. Jurnal Riset Akuntansi Dan Keuangan, 3(1), 562. https://doi.org/10.17509/jrak.v3i1.6604

Fietoria, \& Manalu, E. S. (2016). Pengaruh Profesionalisme, Independensi, Kompetensi dan Pengalaman Kerja Terhadap Kualitas Audit di Kantor Akuntan Publik Bandung. Journal of Accounting and Business Studies, 1(1), 20-38.

Indah Azhari, S. R., Junaid, A., \& Tjan, J. S. (2020). Pengaruh Kompetensi, Independensi, Dan Profesionalisme Auditor Terhadap Kualitas Audit Dengan Etika Auditor Sebagai Variabel Moderasi. Invoice: Jurnal Ilmu Akuntansi, 2(2), 139-184. https://doi.org/10.26618/ inv.v2i2.4116 
Kitiwong, W., \& Sarapaivanich, N. (2020). Consequences of the implementation of expanded audit reports with key audit matters (KAMs) on audit quality. Managerial Auditing Journal, 35(8), 1095-1119. https://doi.org/10.1108/MAJ-09-2019-2410

Kurniawan, S. L. (2019). Pengaruh independensi, Pengalaman Audit, Etika Auditor, Komitmen Auditor dan Time Budget Pressure Terhadap Kualitas Audit (KAP Solo dan Yogyakarta). 1-20.

Nofiyanti, R. (2009). Pengaruh Kompetensi, Independensi, dan Skeptisme Profesional terhadap Kualitas Audit Aparat Inspektorat dalam Pengawasan Keuangan Daerah. 1, 2012.

Nurhayati, E. (2017). Pengaruh Pengalaman, Independensi, Dan Time Budget Pressure Terhadap Kualitas Audit Dengan Etika Sebagai Variabel Pemoderasi (Studi Empiris pada Auditor di KAP Bandung). Jurnal Riset Keuangan Dan Akuntansi, 1(02), 16-27. https://doi.org/10.25134/jrka.v1i02.438

Oklivia, \& Marlinah, A. (2014). Pengaruh Kompetensi, Independensi Dan Ukuran Auditee Terhadap Kualitas Audit. El Muhasaba: Jurnal Akuntansi, 5(2), 226. https://doi. org/10.18860/em.v5i2.2861

Pitaloka, Y., \& Widanaputra, A. A. G. P. (2016). Integritas Auditor Sebagai Pemoderasi Pengaruh Kompetensi Dan Independensi Pada Kualitas Audit. E-Jurnal Akuntansi Unversitas Udayana, 16(2), 1574-1603. https://ojs.unud.ac.id/index.php/Akuntansi/ article/download/20608/15132

Shintya, A., Nuryatno, M., \& Oktaviani, A. A. (2016). Pengaruh Kompetensi, independensi, dan Tekanan Anggaran Waktu Terhadap Kualitas Audit. Seminar Nasional Cendekiawan 2016, 1-19.

Siahaan, S. B., \& Simanjuntak, A. (2019). Pengaruh Kompetensi, Independensi, Integritas dan Profesionalisme Auditor terhadap Kualitas Audit Dengan Etika Auditor Sebagai Variabel Moderasi (Studi Kasus Pada Kantor Akuntan Publik di Kota Medan). Jurnal Manajemen, 5(1), 81-92.

Xiao, T., Geng, C., \& Yuan, C. (2020). How audit effort affects audit quality: An audit process and audit output perspective. China Journal of Accounting Research, 13(1), 109-127. https://doi.org/10.1016/j.cjar.2020.02.002 